\title{
Controlling of Stomphastis thraustica (Meyrick) (Lepidoptera: Gracillariidae) by Using Entomopathogenic Fungi
}

\author{
S.S. Moawad ${ }^{1 *}$, Y.A. Mahmoud ${ }^{1}$, I.M.A. Ebadah ${ }^{1}$, H.E. Sadek ${ }^{1}$ and D.E. Lotfy ${ }^{2}$ \\ ${ }^{1}$ Department of Pests and Plant Protection, National Research Centre, Cairo, Egypt \\ ${ }^{2}$ Plant Protection Research Institute, Agriculture Research Centre, Cairo, Egypt \\ *Corresponding author
}

\section{A B S T R A C T}

\begin{tabular}{|c|}
\hline Keywords \\
\hline $\begin{array}{l}\text { Beauveria bassiana, } \\
\text { Metarhizium } \\
\text { anisopliae, } \\
\text { Stomphastis } \\
\text { thraustica, } \\
\text { Biological control. }\end{array}$ \\
\hline Article Info \\
\hline $\begin{array}{l}\text { Accepted: } \\
28 \text { October } 2017 \\
\text { Available Online: } \\
10 \text { December } 2017\end{array}$ \\
\hline
\end{tabular}

Stomphastis thraustica is a very important pest of Jatropha plant, it causes great losses in the yield (seeds) of the plant which used for production of biodiesel. This work was conducted under laboratory conditions to evaluate the efficiency of two fungus isolates for controlling this pest. This study discover a new biological control method against this pest that benefit for environmental conservation. Our results indicated that the fungus Beauveria bassiana gave $92.2 \%$ mortality against both $5^{\text {th }}$ larval instar and pupa at $1 \times 10^{8}$ conidia / ml concentration while this percentage decreased to $74.4 \%$ with the same previous concentration of Metarhizium anisopliae against the same larval instar. The higher pathogenicity of $B$. bassiana than $M$. anisopliae against $5^{\text {th }}$ larval stage is more obvious with LC50 and LC90 values where they recorded $2.5 \times 10^{5}$ and $3.7 \times 10^{7}$ conidia $/ \mathrm{ml}$ for $B$. bassiana and $1.1 \times 10^{7}$ and $8.9 \times 10^{8}$ for $M$. anisopliae. Although the two fungus isolates are virulent against larvae and pupae of $S$. thraustica, the higher pathogenicity of $B$. bassiana gave it the priority for controlling this pest and the two fungus isolates considered promising alternatives to chemical insecticides and recommended in IPM programs.

\section{Introduction}

Jatropha curcas considered one of the most important wonder plants in recent years. This plant is cultivated in dry tropical conditions for producing biodiesel (Wani et al., 2006; Kumar et al., 2002). This plant is infested by many insect pest among them is Stomphastis thraustica; the leaf miner of Jatropha plant. This pest causes great losses in most parts of Jatropha plant especially the foliage which consequently negatively affects the yields of produced seeds, the main target for biodiesel production (Narayana et al., 2006; Gao, et al., 2010; Rao et al., 2001; Rodrigues et al., 2011). Many trials were conducted for using insecticides to control the insect pests of
Jatropha plant (Cassimo et al., 2011) but till now, there is no any trial to use the biological control agent for controlling this pest. This make up the first attempt to use two strains of entomopathogenic fungi, Beauveria bassiana and Metarhizium anisopliae, for controlling this pest.

\section{Materials and Methods}

\section{Fungus culture}

Isolates of Beauveria bassiana and Metarhizium anisopliae were obtained from Assiutt University, Mycological center, 
Faculty of Science. The isolates were cultured on potato dextrose Agar (PDA) medium containing $20 \mathrm{~g}$ glucose, $20 \mathrm{~g}$ starch, $20 \mathrm{~g}$ agar, and $1000 \mathrm{ml}$ of distilled water in test tubes. These tubes were autoclaved at $21 \mathrm{C}^{0}$ for 15-20 min and incubated at $27 \mathrm{C}^{0} \pm 1,80$ $\% \pm 5 \% \mathrm{RH}$ and photophase of $12 \mathrm{~h}$ for 15 days. The conidia were harvested by scraping the surface of the culture with inoculation needle. The mixture was stirred for 10 minute the hyphal debrise was removed by filtering the mixture through fine mesh sieve. The conidial concentration of final suspension was determined by direct count using Haemocytometer. Serial dilutions were prepared in distilled water containing $0.1 \%$ tween- 80 and preserved at $5 \mathrm{C}^{0}$ until used.

\section{Pathogenic bioassay}

\section{Insect's culture}

Jatropha leaves infested with Stomphastis thraustica were collected from the field in cloth bags and transferred to the laboratory for examination. The infested leaves introduced into covered cage measured $50 \times 25 \times 50 \mathrm{~cm}$ till adult emergence. After then, the mature adults (males and females) were gathered by aspirator and released into other cage provided with Jatropha pots to acts as an oviposition site. The culture was established and maintained under $22 \pm 2 \mathrm{C}^{0}, 55 \pm 3 \% \mathrm{RH}$ and 16:18:D (Ebadah et al., 2017).

\section{Mortality test under laboratory conditions}

The concentration of the stock suspension was adjusted to $1 \times 10^{6}, 1 \times 10^{7}$ and $1 \times 10^{8}$ conidia /ml using Neubaour haemocytometer. To evaluate the pathogenicity of each of the fungal isolate, infested Jatropha leaves with different larval instars were dipped in the fungal suspension with improved concentration for 5 seconds (five replicate were applied) then the treated leaves were kept in petri dish $(15 \mathrm{~cm})$ contain wet tissue for keeping the humidity. After 4 days of observation, all counted larvae were collected to determine how many larvae were dead without being infested with fungal isolates. A control treatment was sprayed with distilled water only.

\section{Re-isolation}

To know the reasons of larval death, they were collected and placed on selective agar discs to show if the morality due to fungal infestation or not. In addition to examine the die larva under stereomicroscopy and pick picture to record symptoms of death (Fig. 1).

\section{Statistical analysis}

The mean number of live larvae per leaf was tested for percent mortality. The data were subjected to analysis of variance (ANOVA) and the means were compared by LSD test at 0.05 levels, using SAS computer program (SAS, 2009). Pathogenicity analysis was done according to Gomez and Gomez (1984).

$\mathrm{CM}(\%)=\mathrm{T}(\%)-\mathrm{C}(\%) / 100-\mathrm{C}(\%)$

Where;

CM (\%)-corrected mortality

T-Mortality in treatment

C-Mortality in control

\section{Results and Discussion}

Table 1 shows the mean percent mortalities of both isolates of entomopathogenic fungi on the different stages of $S$. thraustica the data showed that both tested isolates had more or less degree of Pathogenicity against larvae and prepupae of $S$. thraustica in case of isolate $B$. bassiana, the least concentration $\left(1 \times 10^{6}\right.$ conidial $\left./ \mathrm{ml}\right)$ gave the lowest mortality percent in all larval instar started from 27.8\% 
in $2^{\text {nd }}$ larval instar and ended with $65.6 \%$ in the $5^{\text {th }}$ larval instar, while the highest tested concentration $\left(1 \times 10^{8}\right.$ conidial $\left./ \mathrm{ml}\right)$ started with $64.4 \%$ mortality in $2^{\text {nd }}$ larval instar and ended with $92.2 \%$ mortality in the $5^{\text {th }}$ larval instar. Also, prepupal stage recorded $50.0 \%$ mortality at $\left(1 \times 10^{6}\right.$ conidial $\left./ \mathrm{ml}\right)$ and this percent raised to $92.2 \%$ at $\left(1 \times 10^{8}\right.$ conidial $/ \mathrm{ml}$ ).

In case of isolate $M$. anisopliae the same previous trend of mortality was observed where the mortality percent has positive relationship the applied concentration in all tested staged of $S$. thraustica where the highest mortality percent $(74.4 \%)$ was recorded with $5^{\text {th }}$ larval instar at $\left(1 \times 10^{8}\right.$ conidial $/ \mathrm{ml})$.

Generally, the data in the table 1 shows asymmetric trend of mortality percent in relation to applied concentration of both tested isolated. From these data it is observed that $B$. bassiana is more virulence than $M$. anisopliae against larvae and pupae of $S$. thraustica at all tested concentrations especially B. bassiana recorded $94.4 \%$ and $92.2 \%$ mortality in $5^{\text {th }}$ larval instar and pupal stage at $\left(1 \times 10^{8}\right.$ conidial $\left./ \mathrm{ml}\right)$ this highest mortality percentage give the priority to isolate $B$. bassiana for controlling this pest.

The higher pathogenicity of $B$. bassiana against $S$. thraustica than $M$. anisopliae is more obvious through $\mathrm{LC}_{50}$ and $\mathrm{LC}_{90}$ values in table 2 .

The effected of entomopathogenic fungi were evaluated to determine whether the tested concentrations have high efficacy against larvae and pupae of $S$. thraustica under laboratory conditions.

Both fungal isolates were found pathogenic to larvae and pupae of S. thraustica and there is no relationship between the age of the treated larval instar and both corresponding $\mathrm{LC}_{50}$ and $\mathrm{LC}_{90}$ where $\mathrm{LC}_{50}$ for $5^{\text {th }}$ and $3^{\text {rd }}$ larval instar were $2.5 \times 10^{5}$ conidia $/ \mathrm{ml}$ and $6 \times 10^{6}$ conidia / $\mathrm{ml}$ of $B$. bassiana, respectively and $\mathrm{LC}_{90}$ values of the same isolate for the same previous larval instar were $3.7 \times 10^{7}$ and 7.8 $\times 10^{8}$ conidia/ml, respectively. The same previous trend of $\mathrm{LC}_{50}$ and $\mathrm{LC}_{90}$ towards different larval instars was also observed with M. anisopliae.

Table.1 Mean percent mortality of Beauveria bassiana and Metarhizium anisopliae at different concentrations on the larvae and pupae of Stomphastis thraustica under laboratory condition

\begin{tabular}{|c|c|c|c|c|l|l|}
\hline \multirow{2}{*}{ Treatment } & \multicolumn{5}{|c|}{ Mean percent mortality after treatment } \\
\cline { 2 - 7 } & \multirow{2}{*}{$\begin{array}{l}\text { Conc. } \\
\text { (Conidia /ml) }\end{array}$} & \multicolumn{5}{|c|}{$\begin{array}{l}\text { Larval stage } \\
\text { stage }\end{array}$} \\
\cline { 2 - 7 } & $2 \mathrm{nd}$ & $3 \mathrm{rd}$ & 4 th & 5 th & \\
\hline \multirow{3}{*}{ Beauveria bassiana } & $1 \times 10^{6}$ & 27.8 & 38.9 & 34.4 & 65.6 & 50.0 \\
\cline { 2 - 7 } & $1 \times 10^{7}$ & 57.8 & 69.9 & 64.4 & 82.2 & 74.4 \\
\cline { 2 - 7 } & $1 \times 10^{8}$ & 64.4 & 78.9 & 71.1 & 94.4 & 92.2 \\
\hline \multirow{3}{*}{ Metarhizium anisopliae } & $1 \times 10^{6}$ & 11.1 & 21.1 & 17.8 & 25.6 & 35.6 \\
\cline { 2 - 7 } & $1 \times 10^{7}$ & 29.9 & 38.8 & 34.4 & 49.9 & 46.7 \\
\cline { 2 - 7 } & $1 \times 10^{8}$ & 53.3 & 67.8 & 62.2 & 74.4 & 60.0 \\
\hline \multirow{2}{*}{ control } & water & 7.8 & 11.1 & 7.8 & 2.2 & 13.3 \\
\hline
\end{tabular}


Table.2 Mean lethal concentrations $\left(\mathrm{LC}_{50}\right)$ and $\left(\mathrm{LC}_{90}\right)$ of Beauveria bassiana and Metarhizium anisopliae on the larvae and pupae of Stomphastis thraustica under laboratory condition

\begin{tabular}{|c|c|c|c|c|c|}
\hline \multicolumn{2}{|c|}{ Treatment } & \multicolumn{2}{|c|}{ 95\% confidence limit } & \multicolumn{2}{|c|}{ 95\% confidence limit } \\
\hline \multirow{6}{*}{ Beauveria bassiana } & Treated stage & $\mathrm{LC}_{50}$ & slope & $\mathrm{LC}_{90}$ & slope \\
\hline & $2^{\text {nd }}$ larval instar & $1.2 \times 10^{7}$ & $0.8 \pm 0.16$ & $1.3 \times 10^{9}$ & $0.6 \pm 0.1$ \\
\hline & $3^{\text {rd }}$ larval instar & $6 \times 10^{6}$ & $0.9 \pm 0.18$ & $7.3 \times 10^{8}$ & $0.6 \pm 0.1$ \\
\hline & $4^{\text {th }}$ larval instar & $4.3 \times 10^{6}$ & $0.5 \pm 0.1$ & $5.5 \times 10^{8}$ & $0.6 \pm 0.1$ \\
\hline & $5^{\text {th }}$ larval instar & $2.4 \times 10^{5}$ & $0.8 \pm 0.19$ & $3.7 \times 10^{7}$ & $0.59 \pm 0.12$ \\
\hline & Prepupal stage & $1.8 \times 10^{6}$ & $0.6 \pm 0.11$ & $8.8 \times 10^{7}$ & $0.8 \pm 0.11$ \\
\hline \multirow{5}{*}{ Metarhizium anisopliae } & $2^{\text {nd }}$ larval instar & $9.2 \times 10^{7}$ & $0.5 \pm 0.1$ & $3.1 \times 10^{9}$ & $0.8 \pm 0.1$ \\
\hline & $3^{\text {rd }}$ larval instar & $5.1 \times 10^{7}$ & $0.8 \pm 0.12$ & $2.8 \times 10^{9}$ & $0.7 \pm 0.1$ \\
\hline & $4^{\text {th }}$ larval instar & $3.8 \times 10^{7}$ & $0.7 \pm 0.2$ & $1.6 \times 10^{9}$ & $0.8 \pm 0.1$ \\
\hline & $5^{\text {th }}$ larval instar & $1.1 \times 10^{7}$ & $0.9 \pm 0.1$ & $8.9 \times 10^{8}$ & $0.7 \pm 0.1$ \\
\hline & Prepupal stage & $5.7 \times 10^{7}$ & $0.8 \pm 0.12$ & $1.5 \times 10^{11}$ & $0.4 \pm 0.12$ \\
\hline
\end{tabular}

Fig.1 Reisolation on agar media to distinguish between larval mortality due to fungus (A) or due to other reason $(\mathrm{B})$

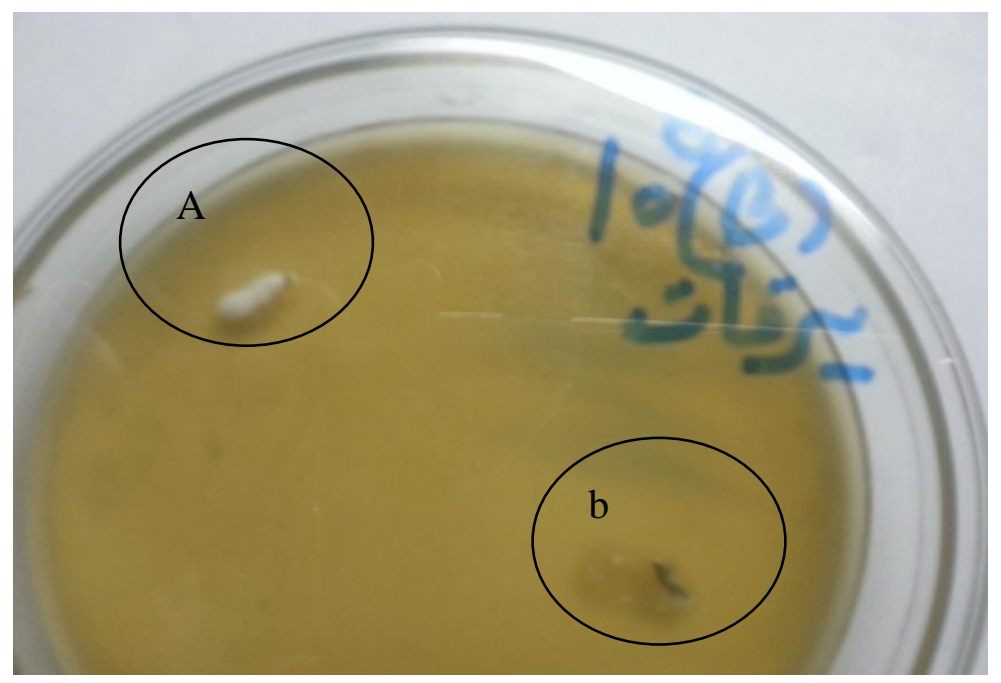

Fig.2 Larval mortality symptoms after $96 \mathrm{hr}$ of fungal treatment. Arrow indicated to hyphal growth on the cuticle surface. $A=3^{\text {rd }}$ larval instar, $\mathrm{B}=5^{\text {th }}$ larval instar

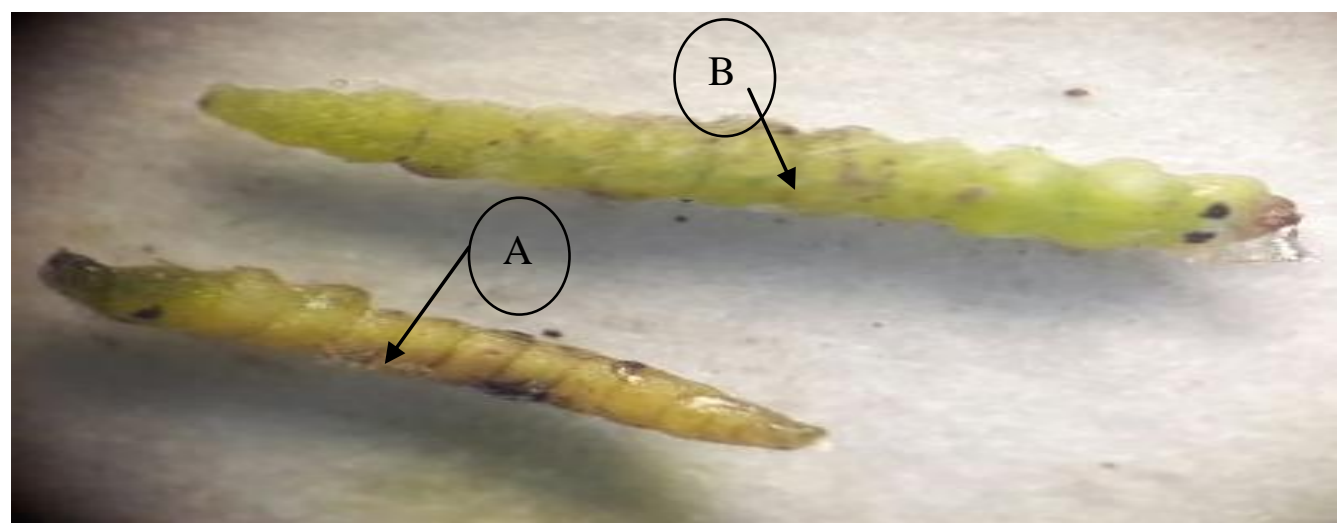


Fig.3 Pupal mortality symptoms after $96 \mathrm{hr}$ of fungal treatment

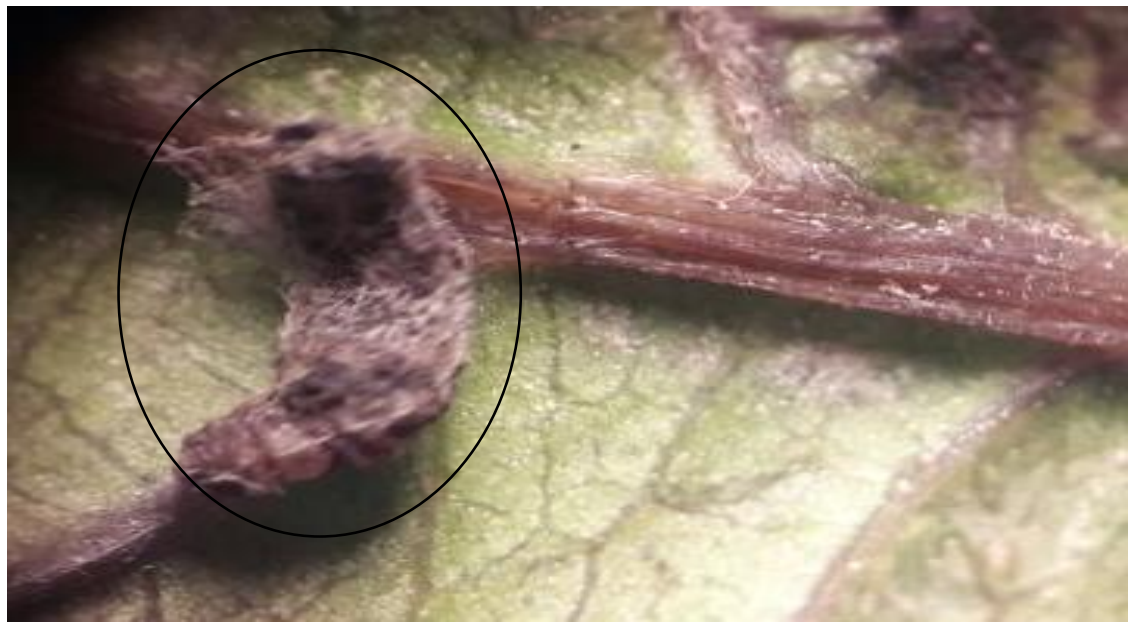

The data in table 2 shows that there are negative relationships between $\mathrm{LC}_{50}$ and $\mathrm{LC}_{90}$ and the age of the treated instar, this is mean that the earlier instar is less sensitive to both fungal isolates than older ones. Also, it is noticed that prepupae of $S$. thraustica is more sensitive to both fungal isolate than larval stage at any concentration. The symptoms of the larval death due to fungal infection are clearly observed in figures 1,2 and 3.

The amount of conidia used to attain concentration and thus, achieving an efficacious penetration of the fungus on the cuticle of the treated insect stage and causing host death. Similar finding by Garcia et al., 2011 were obtained on the efficiency of $B$. bassiana and $M$. anisopliae on Spodoptera fungiperda and Epilachna varivestis larvae at six concentration $\left(10^{4}\right.$ to $\left.10^{9}\right) ; B$. bassiana was more virulent for $E$. varivestis larvae with 93.3\% mortality. B. bassiana strain presented the highest mortality on $S$. fungiperda larva. On the other hand, our results disagreed with Khalid et al., 2012, evaluating the pathogenicity of both $B$. bassiana and $M$. anisopliae on $G$. mellonella larvae using concentration $10^{2}$ to $10^{6}$ conidial $/ \mathrm{ml}$.

Our results agree with that of Cabello et al., 2009 where stated that; the higher mortality of
T. absoluta larvae under laboratory condition indicated that $B$. bassiana cause moderate larval mortality.

Our results confirmed the finding of Shalaby et al., (2013) on T. absoluta they stated that the earlier larval instar is more sensitive to $M$. anisopliae than the older larval instars. Dahliz (2014) have reported similar results with $M$. anisopliae. Our results confirmedly agreed with the study of Inani and Oldarge (2012); they compared the pathogenicity of $B$. bassiana and $M$. anisopliae on T. absoluta larvae and indicated the higher efficiency of $B$. bassiana against $T$. absoluta larvae.

Our results also indicated the potential of $B$. bassiana isolate in controlling the larvae of $S$. thraustica and can be included in IPM programs. Neves and Alves (2002) noted,as more conidia penetrating, more toxins or enzymes are released, increasing the insect mortality, though, the fungus action speed depends, besides the concentration, of the host species involved (Sosa-Gomez and Moscardi, 1992). According to Klespies and Zimmermann (1998), variation in virulence of entomopathogenic fungi is a result of differences in the enzymes and toxins production in conidia germination speed, mechanical activity in the cuticle penetration, 
colonization capacity and cuticle chemical composition.

The use of entomopathogenic fungi different insect pest seems to promising insecticide alternative and its efficiency trusted by many authors. Our results indicated that the most effective percent mortality of tested fungal isolates was found in $B$. bassiana than $M$. anisopliae in all treated larval instars besides the pupa of $S$. thraustica. Both isolates could be very well utilized as safe alternatives to chemical insecticides for controlling $S$. thraustica especially our study make up the first attempt to use the entomopathogenic fungi against $S$. thraustica. It might be concluded that $B$. bassiana than $M$. anisopliae show different pathogenicity cause mortality of insect from early to last larval instar besides the pupal stage and the higher efficiency of $B$. bassiana against $S$. thraustica give it the priority for controlling this pest than $M$. anisopliae. Therefore, further study under field conditions should be occurred to evaluate the efficiency of these formulations for controlling this pest.

\section{References}

Cabello, T., Gallego, J.R., Vila, E., Soler, A., Pino, M., Carnero E., HernándezSuárez, A. and Polaszek, A. 2009. Biological control of the South American Tomato Pin worm, Tuta absoluta (Lep.: Gelechiidae), with releases of Trichogramma achaeae (Hym.: Trichogrammatidae) on tomato greenhouse of Spain. Integrated control in protected crops. Mediterranean climate IOBC/wprs Bulletin 49: 225230.

Cassimo, A.C., João, E.C.B., Coelho, J.P. and Santos, L. 2011. Evaluation of insecticide doses for the control of Jatropha leaf beetle and Jatropha leaf miner in Mozambique. African Crop
Science Conference Proceedings 10: 187-190.

Dahliz, A. 2014. Complex of natural enemies and control methods of the exotic invasive pest Tuta absoluta (Lepidoptera: Gelechiidae) in Southern Algeria BP17, Touggourt (Algeria).

Ebadah, I.M.A., Moawad, S.S., Sadek, H.E. and Mahmoud, Y.A. 2017. Morphological Depiction and Life Table of Newly Recorded Jatropha Leaf Miner Stomphastis sp. Stages in Egypt. J. Entomol., 14: 122-127.

Gao, S.Q., Jaqu, Q.U., Chua, N.H. and Ye, J. 2010. A new strain of Indian cassava mosaic virus causes a mosaic disease in the biodiesel crop Jatropha curcas. Arch. Virol. 155:607-612.

Garcia, C., Gonzalez, M., and Bautista. M. 2011. Pathogenicity of native entomopathogenic fungal isolates against Spodoptera frugiperda and Epilachna varivestis. Rev. Colomb. Entomol. 37: 217-222.

Gomez, K.A. and Gomez, A.A. 1984. Statistical Procedure for Agricultural Research. John Wiley and Sons, New York, NY, USA, 680 pp.

Inanl, C., and Oldargc, A.K. 2012. Effects of entomopathogenic fungi, Beauveria bassiana (Bals.) and Metarhizium anisopliae (Metsch.) on larvae and egg stages of Tuta absoluta (Meyrick) Lepidoptera: Gelechiidae. Ege Üniversitesi Ziraat Fakültesi Dergisi 49: 239-242.

Khalid, A.H., Mohamed, A.A.A., Ahmed, Y.A. and Saad, S.E. 2012. Pathogenicity of Beauveria bassiana and Metarhizium anisopliae against Galleria mellonella. Phytoparasitica 40:117-126.

Kleespies, R.G., and Zimmermann, G. 1998. Effect of additives on the production, viability and virulence of blastospores of Metarhizium anisopliae. Biochem. 
Sci. Technol. 8: 207-214.

Narayana, D.S.A., Shankarappa, K.S., Govindappa, M.R., Prameela, H.A., Rao, M.R.G. and Rangaswamy, K.T. 2006. Natural occurrence of Jatropha mosaic virus disease in India. Curr Sci, 91: 584-586.

Neves, P.J. and Alves, S.B. 2000. Selection of Beauveria bassiana (Bals.) and Metarhizium anisopliae (Metsch.) Strains for control of Cornitermes cumulans (Kollar). Braz. Arch. Biol. Technol. 43: 319-328.

Rao, B.T., Lakshmi, B.B. and Rao, L.M. 2001. Medico-Ethnology and conservation of medicinal plants of Paderu forest division- Visakhapatnam. Ecol. Env. Cons. 7: 117-131.

Rodrigues, S.R., de Oliveira, H.N., dos Santos, W.T. and Abot, A.R. 2011. Biological aspects and damage of Pachycoris torridus on physic nut plants. Bragantia 70: 356-360.
SAS. 2009. Statistical analysis system software. Ver. 9.1. SAS Institute Inc., Carry. NC

Shalaby, H.H., Faragalla, F.H., El-Saadany, H., and Ibrahim, A. 2013. Efficacy of three entomopathogenic agents for control the tomato borer, Tuta absoluta (Meyrick) (Lepidoptera: Gelechiidae). Natu. Sci. 11: 63-72.

Sosa-Gómez, D.R., and Moscardi, F. 1992: Epizootiology: Key of the problems for the microbial control with fungi. In: Symposium of biological control, 3, 1992, Águas de Lindóia. Anais. Jaguariúna: EMBRAPA-CNPDA. pp. 64-69.

Wani, S.P., Osman, M., D'silva, E. and Sreedevi, T.K. 2006. Improved livelihoods and environmental protection through biodiesel plantations in Asia. Asian Biotechnol. Develop. Rev. 8: 11-29.

\section{How to cite this article:}

Moawad, S.S., Y.A. Mahmoud, I.M.A. Ebadah, H.E. Sadek and Lotfy, D.E. 2017. Controlling of Stomphastis thraustica (Meyrick) (Lepidoptera: Gracillariidae) by Using Entomopathogenic Fungi. Int.J.Curr.Microbiol.App.Sci. 6(12): 3976-3982. doi: https://doi.org/10.20546/ijcmas.2017.612.458 